\title{
The Staging of Examinations: A Student Response to the Institutional Perspective
}

\author{
DANIEL ALBAS* and CHERYL ALBAS*
}

\begin{abstract}
When universities administer examinations, they do so dramaturgically. That is, they use spaces, props, equipment, and bodies to convey specific messages (that examinations are important, serious, formal affairs which reflect the larger societal values of universalism and individualism) to students. Drama and dramaturgy require both actors and an audience; the interaction consists of the effect that the one has on the other, that the other has on the one and both of these. The focus of this paper is on the interaction between the message and students' response to it, that is, the students' definition of the situation. In particular, emphasis is upon the notion that the dramaturgical messages given by the university will be interpreted largely as they were intended to be, that in some cases the effect of the message is dysfunctional, either because it is misinterpreted or because it is challenged.
\end{abstract}

\section{RÉSUMÉ}

Lorsque les universités font passer des examens, la dramaturgie est toujours présente. Elles font appel à des lieux, des accessoires, du matériel et des personnes pour transmettre aux étudiants des messages précis (que les examens sont importants, sérieux et officiels et qu'ils reflètent les valeurs sociales plus importantes de l'universalisme et l'individualisme). Le théâtre et la dramaturgie exigent tant des acteurs que des spectateurs; c'est grâce à l'effet que l'un a sur l'autre et que l'autre a sur l'un que l'interaction se produit. Cet article porte sur l'interaction entre le message et la réaction des étudiants à celui-ci, c'est-à-dire comment les étudiants voient la situation. On insiste particulièrement sur l'idée que les messages dramaturgiques lancés par l'université seront en grande partie interprétés comme prévu et que dans certains cas, le message est pertubateur, soit parce qu'il est mal interprété, soit parce qu'il est contesté.

*Department of Sociology, University of Manitoba

An earlier version of this paper was presented at the Qualitiative Research Conference: Interactionist Research '88, Windsor. The authors wish to thank D. Rennie for comments on earlier drafts of this work. 
In a previous paper (Albas and Albas, 1988) we show that when universities administer examinations they do so dramaturgically; that is, they use spaces, props, equipment, and bodies to convey specific messages to students. These messages are meant to convey the fact that examinations are important, serious, formal affairs which reflect the larger societal values of universalism and individualism. In that paper we attempted to project our construction of what we imputed the university message to the students to be, based on information from university officials and our own observations, and the description of this within a framework of dramaturgical insights and terminology. Both drama and dramaturgy require both actors and an audience; the interaction consists of the effect that the one has on the other, that the other has on the one and both of these. Whereas the focus of the previous study was on the message and the media, the focus here is on the interaction between the message and students' response to it, that is, their definition of the situation. In particular, emphasis is upon the notion that the dramaturgical messages given by the university will be responded to dramaturgically.

The definition of the situation enunciated by W. I. Thomas is a widely known theorem of sociology bandied about with little reflection on its underlying complexity, which indeed was not made as clear by him as it might have been. Thomas fails to show, for example, how society cues its members on what a given situation is or even what a situation is supposed to consist of. These enigmatic aspects have been elucidated by Perinbanayagam (1974) who shows that what Thomas calls a definition of the situation is a synthesis of the intended message on the part of whatever agency sets up the situation (for example, an institution) and the response to this message by those affected by the institution. Perinbanayagam stresses that such a response although subjective on the part of the respondent is nevertheless limited by structural parameters imposed by the institution or agency in the first place. In effect, there is "a rivalry", as he calls it, between individuals" subjective definition of the situation and the one intended by the institution. The result of this rivalry is a synthesis which comprises the definition of the situation.

\section{METHOD}

The data were gathered over the last 15 years from our own and other university classes (Albas and Albas, 1984). The methodological process involved triangulation wherein data of different kinds were collected from a variety of sources in such a way that the weaknesses of one research technique were compensated for by the strengths of another thus better ensuring reliability and validity. The main sources from which data were gathered for this paper were exam logs, observation and probing for meaning, and surveys.

The exam logs included descriptions of thoughts, sentiments, and behavior which students considered significant from the first day of classes up to and including the return of their examination grades. Over time these logs were 
collected from approximately three hundred students. They came from all ages and stages (freshmen to seniors) in the academic career, all achievement levels (failures to top achievers) and a variety of statuses (single, married, divorced, and single parents). These records served as a valuable source of information about the inner life of students which we were in no position to observe. The contents of these "logs" were not accepted by us uncritically. We also interviewed many of these students to get clarification of ambiguous statements and verification of any surprising or unexpected events. For example, we asked questions such as "Do you really mean that you did this? Did it seem to you that [this] was what was happening?"

In addition, we often approached students who were behaving in an unusual manner and asked them why they did these things. For example, during the exam one student accidentally kicked over a pile of books and notes piled on the floor under his desk. As he reached down with his hands to reorder the pile, he suddenly realized that he was being observed by an invigilator. In mid reach he froze and proceeded to attempt to rearrange the pile, this time with his feet. When asked why he behaved in this manner, he replied "A smoking gun is more creditable in the hand than at the feet." Another source of valuable data was surveys where we asked students who had not submitted logs the meanings they attributed to the various aspects of institutional staging. These surveys resulted in an additional data base against which previous information was evaluated.

We did not rely on examples of bizarre behavior but based our description on observations reported or displayed by an appreciable number of students. Throughout the years we asked dozens of students to read the reports we prepared and to assess the validity of our conclusions from their points of view. On occasion, as a result of this feedback we have modified and recast our theorizing.

\section{DISCUSSION}

Our procedure will be to show in tabular form how specific messages by the university were transmitted through the media of spaces, props, equipment, and bodies and how they were responded to by the students via these same media.

In the table shown on next page the media categories of space, props, equipment and bodies are shown in Column I. Column II shows the message imparted by the particular medium. In turn, Column II is divided into two sub-columns captioned "value" and "norm". The value refers to the goal which the institution is attempting to achieve and which, in itself, represents goals of the larger society, for example, achievement, individualism, order, rationality, etc. The norm refers to specific exam room behavior expected of students which is consistent with the corresponding value. On the right hand side of the table, the student response column summarizes the subjective reports by students describing their interpretation of the message and the ways in which they responded to it.

In the table, of course, it is possible to list only summary phrases which typify 
Table 1. Schematic Representation of Student Response to Institutional Messages in the Staging of Examinations

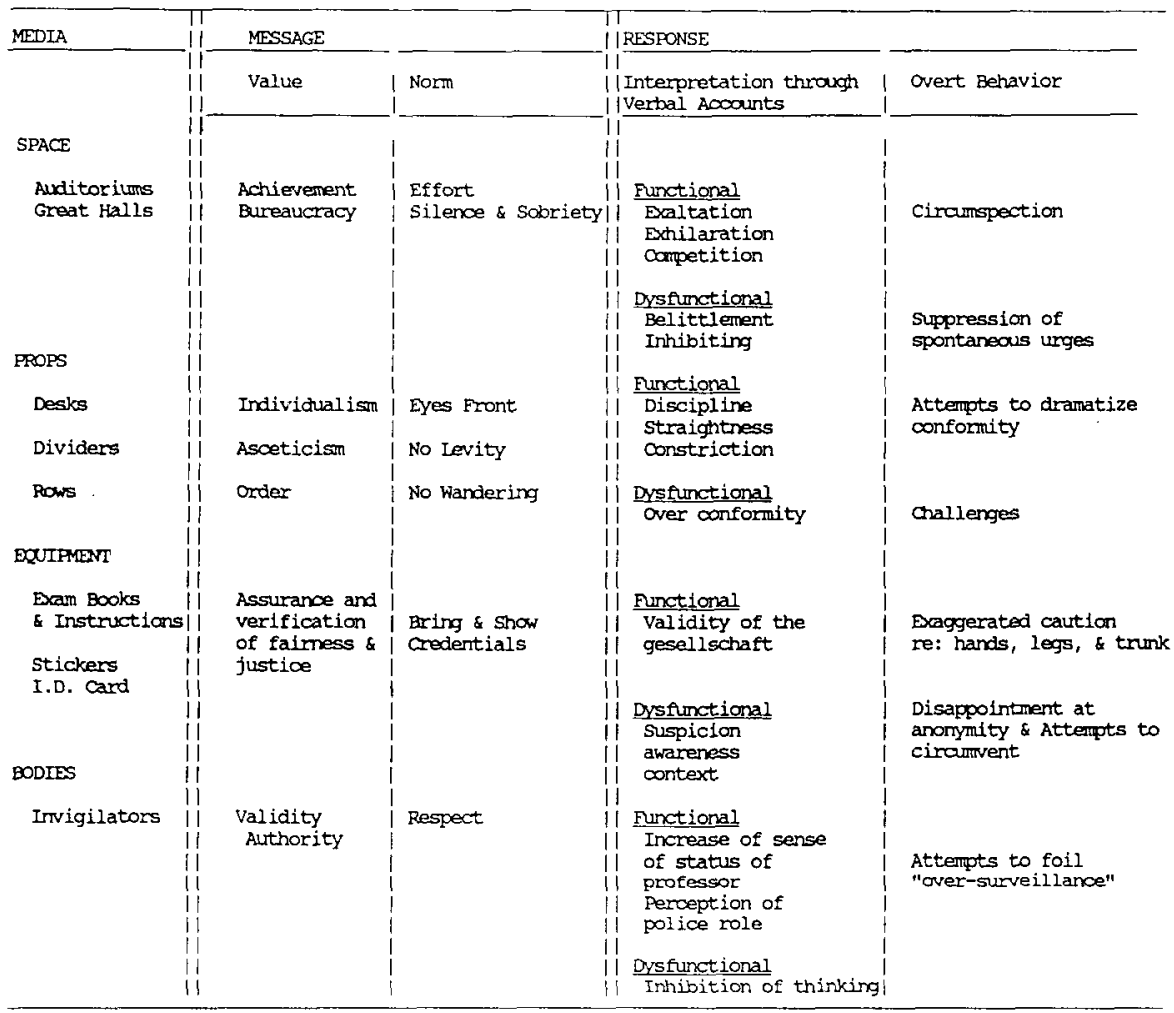

student responses. We now attempt a more detailed discussion of them and show in the process the variations, subtleties and overlappings of student response behavior.

\section{SPACE: Student Response to Institutional Messages Regarding Achieve- ment, Bureaucracy, Effort, Silence, and Sobriety as Mediated by Space}

The summarizing phrases employed in the table to typify student response to the first message (achievement) are "an air of industry" and "transformation of a fun place to an arena of ordeal". Perhaps the most dramatic impact on students who are entering the large examination rooms (transformed gymnasiums) comes in the form of the door opening ritual:

"When the day of the exam arrives all the students congregate in front of the large doors which open into the gymnasium. It seems so official to have to wait outside the locked doors until the dot of the formally appointed hour."

It is important to note the students are usually packed closely and excitedly in a rather narrow, dimly lit corridor where they confront the locked doors. This 
situation is very different from ordinary classrooms where doors are open and students are accustomed to drift in casually. As the student quoted above indicates "on the dot of the formally appointed hour", the doors open and a solid mass of students pour into the large, brightly lit, examination room. Those in the front and in the middle are carried on the surge of the crowd of those behind almost as if, as one student puts it, they are "individual fish in a school swept by the tide". In response to the light, the space and pushing urgency of the crowd, they fan out to their favored locations for writing, and pick their individual seats. In the logs and interviews they repeatedly note that when they enter the exam room they are struck by the intense brightness of the lights. Their response is not merely in accordance with the principles of psycho-physics, they also attribute institutional meanings:

"The effect of the brightness on me was to make me think that everything is in the lime light now, no funny business!"

"It's almost like they have so much light in the room because they want you to know that they want to see everything you are doing."

The vast area of the room and its soaring ceiling are noted by students and seen to reinforce the message associated with the light:

"The bigness of the room and the way in which everything is laid out has the effect of scaring you into not doing anything you're not supposed to do".

This setting of space and light is most emphatically seen to convey a message of sobriety and appropriate bureaucratic behavior:

"The larger the exam hall, the more impersonal everything becomes".

"When you walk in to write [the exam] in such a large, official setting, that is when you really feel that you have become your student number".

Students who are for the first time writing an exam in such a formal setting with its soaring ceilings and vast area often report feelings which they describe as awesome.

"The first time I entered Bison East [the largest gymnasium on campus] to write an exam, I looked up and felt awed by the height of the ceiling and the overall bigness of the place. It really hit home that something powerful was looking down upon what I was about to do. This feeling that I had of almost awe is something peculiar to exams. I can't ever remember feeling this way when I've entered the same place to watch a basketball game".

Indeed, it is understandable that while the student may not have felt awe in that same room when attending a basketball game, when he was under the spell of the pre-examination ordeal, he would approach the area with predispositions to humility and subservience:

When I enter the exam room I feel subordinate because I believe I am now placed in a position where I have to prove myself.

These feelings are activated and augmented by the specific examination-related dramaturgical cues. In effect, students, as Stebbins (1975) indicates, would build 
an environment for themselves, partly on the basis of their own psychological set and partly on the basis of cues in the staged environment which are intended to produce the particular psychological set in the first place. Feelings of being awe struck are further elaborated by students who indicate that as they enter the exam room and wish their friends a last "good luck", the "wish comes out as a whisper".

Once seated, students, particularly the more able ones, are likely to report a feeling of exhilaration and even exaltation which is not due merely to the challenge of competition but in their own words:

I like butterflies in the tummy that come with big exams. When I get them I know I've got the edge. It's a mental high that makes me feel like nothing is going to stop me; I'm going to ace it and I know it.

The bigness of the place seems to make the exam more important and gives me that extra surge of adrenalin which helps me to think more clearly and concisely. I also find that I can write down my thoughts more quickly. .I turn into a think machine.

Consistent with these feelings of exaltation, are reports from students who state that they feel the weight of responsibility to perform beyond their usual capacities. One student expresses shame at under performing in such an awesome setting in the following way:

I feel even more embarrassed and guilty writing bullshit in a room like this than I would in a normal classroom.

When the official word is given to begin writing a perceptible hush settles over the examination hall which many students describe as being unusually noticeable because of the cavernous effect of the large area:

If a pin dropped twenty feet away it could be heard. If the situation is this serious, then you had better watch out.

Another student indicates "the atmosphere is almost one of reverence". The significance of this awesome, almost religious silence lies in a message of importance and seriousness which we hypothesized the university wishes to send to students and which, on the basis of the cited quotes from students and dozens of similar ones, indicates that the students have indeed received. An interesting aspect of this message of seriousness and importance transmitted by the institutional staging is that it seems to be amplified by the students' response to it. For example, students report that the "reverent" atmosphere suppresses their urges to cough, sniffle, or even shift their feet for fear of breaking the spell.

It's so quiet you don't dare cough, sneeze or even clear your throat. You hold it back until you hear someone else doing it.

In those large settings coughs and sneezes sound like bombs going off.

In restraining themselves, students add to the objectivity and strength of the emergent atmosphere of silence which in turn confronts them with even greater force. As Mead (1964:86) indicates "the individual and environment ... mutually determine each other". 
There is a dysfunctional aspect to the spatial impact of institutional staging that must be mentioned because it pertains to the message received or at least interpreted by a large proportion of students. Many students report that the size of and silence in the examination room have a belittling effect upon them:

I've felt dwarfed and intimidated by the largeness and quietness of the place. It has even led me to question my significance in the whole thing.

For some students, the effect can be so inhibiting that they do not feel free to request clarification of questions from invigilators or to leave the exam early even if they have finished. In the latter case they wait until someone else leaves also. In sum, then, the overall effect of space appears to be a positive one since it is in the direction intended by the university and it also contributes to an enhancement of students' feelings and performances. However a residue of a negative effect occurs for some students who report feelings of belittlement and impotence as a result of being dwarfed by the huge areas.

\section{PROPS: Student Responses to Institutional Messages Regarding Individual- ism, Asceticism, and Order as Mediated by Props}

Props may be defined as those features of a setting which are fixed and remain so for the duration of the drama (Gross and Stone, 1981). The props used in the exam drama are the writing tables, chairs and the plywood dividers between the tables. These furniture props have two striking characteristics; one, their rigid geometric arrangement in straight rows and columns and two, their ascetic roughness and hardness. As noted in the table, we hypothesized that the message intended by the university carried the values of individualism, order, and asceticism. The norms implied by these values are that students ought to maintain an "eyes front posture" at all times, they should evince seriousness rather than levity and in general, they ought to comport themselves compactly; that is, there is to be no dangling of legs or arms, or twisting of the head. The interpretation of any response to these messages by students falls under two headings; compliance and challenge.

\section{Complying Responses}

The geometric order in the arrangement of props clearly implies to many students a sense of discipline, straightness, and even constriction (which may or may not be truly functional as is shown below):

Everything about the place seems to convey that I should come in quietly, find a seat, look only at my paper, and hardly move an inch until I'm finished.

The straightness of the rows suggests 'No crooked stuff here'.

The rows are so straight that if you turn your head you feel guilty of breaking the pattern.

The straight lines and grim faced profs blare out 'order'.

The set up blocks every urge I have to relax and stretch - even to get a kink out of my neck. 
Even if the 'blinker' partitions are ineffective in blocking the sight of papers from others, they certainly have the effect of killing any temptation to cheat.

Once, I came into an exam after an all night study session. I would have loved to scrunch my body down and relax but the chair was so angular and so hard I couldn't. It was a forceful reminder that the ordeal had another two hours to go.

Those chairs are built so that if you relax or even lean back in them you might appear to be cheating.

Even students who may appear not to comply are actually doing so as is illustrated by the following case:

My neck became so stiff that I had to turn my head from side to side in order to ease the pain. So that it would not appear as if I might be cheating I closed my eyes when I turned my head.

Another student stated he removed his glasses before he moved his head or relaxed his posture to demonstrate that "I couldn't cheat if I tried".

In all these previous responses it is clear that students did receive the message intended by the university and also that they went to extreme and sometimes painful ends to comply with it.

\section{Challenge Responses}

A small minority of students implied by their responses that they received different messages, or that if indeed they did receive the university's intended message, they did not elect to comply with the letter of the norm at every point. As one of them indicates: "I rebel against this conformity to symmetry". Despite the boldness of statements such as these nearly all students do end up complying with the spirit of the norm. They do so, however, in such a manner that their individualities are not overly constricted or even confined. These types of students bring into the exam setting pieces of their own personalities and relationships. The following quotations illustrate this somewhat paradoxical implication:

On occasion I have stuck my foot out across the aisle so that I can assume a more comfortable [body] position. It also serves to reduce the surveillance aspect of the exam because it prevents invigilators from walking up and down that aisle.

On one occasion I purposefully started to stare at a point under the table. As I expected, an invigilator was behind me, just like a hawk. When she saw that I was not cheating she walked away and remained at the other end of the room for the duration of the exam. I often look around me; sometimes I catch my friends' eyes and we nod to each other. I refuse to cease being a human being just because I'm writing an exam.

Anybody who really wants to cheat can do it, in spite of all the song and dance (of invigilators).

Clearly none of these students represented by the excerpts (admittedly exceptions) admitted to cheating and probably did not. On the other hand, it is also clear that they all rebelled against the official asceticism and felt it necessary to assert their individuality. 


\section{Other Miscellaneous Responses}

A number of student respondents indicated perceptions on their part of messages other than those we hypothesized that the institution means to send. In addition to being simply different, these interpretations suggest that the staging might have been dysfunctional because it is conducive to canned, conventional uncreative thinking rather than to bold imaginative thought. One student noted that "the line up of chairs and tables reminds me of a factory and so disposes me towards assembly line thinking". Also, other students noted that they are so cramped and inhibited by the staging that at critical points they sometimes can not think:

When I encounter a mental block I find that the need to remain so fixed in one place interferes with my thinking. Since the mental block results from the area I' $m$ in, if I could only turn my head around and focus on a new area I'd be able to overcome it.

Yet other students glean from this staging a message of intense and dramatized competition:

As I sit at my table and glance ahead or even from left to right, I feel as if I'm in a swimming race and that $I$ have to catch those people ahead of me or at least keep up with those who are alongside me.

\section{EQ U I P M N T: Student Response to Institutional Messages Regarding Assur- ance and Verification of Fairness and Justice}

Examination equipment refers to those objects which are moved about and handled as part of the drama to supply additional meanings and messages (Gross and Stone, 1981). The major pieces of equipment in the examination drama are I.D. cards which students must place on their desks so they can be examined by the invigilators, offset printed question papers or booklets, and answer booklets. Listed on the cover of the answer booklets are ten instructions cautioning students against such things as removing any of the pages, having any unauthorized material in their possession. The instructions also direct students to fill in their names, students' numbers, etc. on the cover of the booklet and to cover all of this information by affixing a gummed flap over it to ensure anonymity. The clear message conveyed by the use of this equipment is that fairness, justice and complete equality of treatment for all is assured and verified.

Student response to this message is clearly a sense of the gesellschaft as well as an unmistakable "suspicion awareness context" (Glazer and Strauss, 1981). The response of most students to the sense of gesellschaft which comes in demanding I.D. cards, covering their names on the answer booklets and in general conforming to the strictures of uniformity is that it is fully justified. And even if they find it irksome, shocking or as in one or two cases, even mystifying, they comply. In regard to the suspicion awareness context, students go to great pains to display exaggerated shows of compliance with the norms of the situation. These observations are illustrated by the following typical quotations:

Because there are so many students writing the exam it would not be possible for any invigilator to know all of them. Since some students do try to cheat by 
having someone else write the examination for them, it seems that I.D. cards are the only solution.

If I have to blow my nose I make a sniffling sound first. When I have attracted the invigilator's attention I indicate by wrinkling up my nose that I need to blow it, and while he/she is watching me I take the kleenex out of my purse and complete the operation. Contrary to convention and my own habit I leave the snotty kleenex open on the table for all who wish to see it, just so I won't be suspected of cheating.

Students who, though completely innocent, perceive that they appear suspicious because of some suggestive gesture or movement often come to exams prepared with excuse formulas to deliver in the event that they are challenged.

Some students, who, during the term have worked hard at cultivating the acquaintance of benevolent professors, feel irked at exam time when they must conceal their identity on the exam answer booklet with the flap which will cover their name because the favorable impression they hoped they established is now hidden. In an attempt to overcome this barrier, a few of them note that when they write their names on the booklet they press inordinately heavily with their pens and leave the first page blank in the hope that any impression of their name, however faint, will be noticed by the professor when the booklet is opened.

Other students write admiring messages to the professor, humorous quips, or whatever they think will induce some special attention, despite the official norms of anonymity. Still others, who are outright cynics, doubt that professors are disciplined enough not to peek at the names before they read the papers. They read the whole equipment drama as phoney:

I suspect that professors peek under the flap before they start grading so I not only fill in my name, etc. but also give myself titles like 'Defender of the Faith'. I may also make the prof privy to my baptism, confirmation, and maternal names. I've also written jokes. Even if the prof does not decide to peek, it reduces my exam stress. If the prof peeks he/she may decide to be more generous to a student who has a sense of humour.

To further the theme of the cynical views some students have of professors, another one notes:

When I take a course which has been team taught, I face a real dilemma in knowing who to list as senior instructor in the space provided on the answer booklet for the professor's name because I know how status conscious they are about these things, when they publish papers together. If I guess incorrectly it might cost me a grade point or two.

\section{BODIES: Student Response to Institutional Messages Regarding Authority and Surveillance}

In addition to spaces, props, and equipment in examination settings we also need to consider the bodies of the actors themselves. Bodies are the most important elements in projecting dramaturgical messages because the actors think and move, act and react with "body language". The actors involved in the examination drama 
The Staging of Examinations: A Student Response

to the Institutional Perspective

are invigilators [professors and perhaps graduate students]. Invigilators direct students to their seats, give the commands to begin and stop writing, provide extra supplies when necessary, answer questions, provide clarifications of questions when necessary, and patrol the examination room constantly to make sure that all is as it should be. Clearly the message projected by the university through these bodies is one of authority, surveillance, and possible punishment when rules are breached.

The reaction of students to invigilators is an intensified sense of their status and also an increased awareness of their police function. While both of these aspects of professors also exist during the regular term, students almost universally attest to their enhancement and intensification at exam time. The following excerpts illustrate the effect of the presence of professors and other invigilators on students who are writing an examination:

The authority that professors have seems to loom so much larger at exam time.

The exam room reeks with suspicion and surveillance; there are all of those partitions between desks and all of those patrolling professors.

Invigilators dehumanize exams. Once I tried to smile at one of them, just to make the environment a little more human - my efforts were in vain.

I'm careful not to put my hands under the desk because it might look suspicious...like I'm trying to dig for something.

A clearly dysfunctional aspect of invigilation is represented by the widespread response of students embodied in this typical excerpt:

Having an invigilator look over my shoulder blocks my thinking and inhibits my writing.

\section{CONCLUSIONS}

We began this paper by suggesting that the definition of the situation is a composite of a message and a response to it. In a previous paper (Albas and Albas, forthcoming, 1988) we argued that the staging of examinations carries with it certain explicit messages: in this paper we spell out the response to the messages established in the previous work. Our purpose now is to show that the interactions between the institutional messages and the students' responses to them constitute in each case what can be considered to be their interpretation of the message (i.e., their definition of the situation). In most cases it would appear that the student interpretations and reactions are congruent with the messages. In a few cases, for example, the perceived status and police role of the invigilators is exaggerated by the students while in other instances even though the students' interpretations of the message were as intended, their reactions were somewhat deviant and challenging. Precisely because their interpretation seemed to clash with something else within themselves, the definition of the situation was one of challenge.

These two abberations, namely the perception of exaggerated status of professors and the regarding of ordinary rules as challenges are very much the exception. By far the majority of students did appear, from their comments to us, 
to have correctly interpreted the institutional messages as they were sent and to have attempted to comply faithfully with them. As stated in the introduction, Perinbanayagam stresses that the institution does permit a certain subjectivity of interpretation on the part of respondents to the messages provided that these responses are within permittable parameters. One interesting case of such a subjective response to the message permitted by the university during exams occurs when students, who feel themselves overpowered by the formality of the situation, bring with them to the examination room an assortment of dramaturgical equipment. This equipment sometimes takes the form of dressing in comfortable old clothes which the student would ordinarily never wear to school but which has been the study uniform or, glasses rather than contact lenses which are normally worn or munchies (lifesavers or smarties). This baggage helps to reproduce the home study environment. Such a student Goffman (1959: 80-81) would suggest is "taken in by his own act, convinced at the moment that the impression of reality which he fosters is the one and only reality ... the performer comes to be his own audience ... performer and observer of the same show". As a result, the examination setting is transformed into a homey place, and in effect, reduces the anxiety. Other students throw further light on this "little world" they generate around themselves to provide insulation from the overbearing effect of the institutional staging. It appears that after students reach a more advanced stage in their academic careers they learn by practice to cope with the institutional pressures. They become inured to them and so no longer require the dramaturgical props and equipment to generate the "little world" but are now able, as it were, to "switch it on" by assuming the appropriate psychological set. As a matter of fact, senior students who have written LSAT, MCAT and GRE'S [in which they are escorted to their preassigned seats, finger printed, sometimes asked for passports and where any breach of regulations is regarded as an infringement of the law of the land, i.e., a criminal offence] say that they now find university examination regulations "to be rather loose".

One last point to note is that in the case of invigilators, props, and equipment, when the university meant to imply authority and uniform treatment of all and students interpreted it as establishing a suspicion awareness context, we referred to this in the previous paper as a rhetoric of idealization on the part of the university. That is, an exaggerated overfulfillment of the value of universality. We may regard the student reactions described in this paper as a rhetoric of legitimation (Ball, 1970); that is, an exaggerated over-doing of the shows of honesty and compliance so as to counter any aspersion of deviance that might be cast their way.

\section{REFERENCES}

Albas, D. and C. Albas (1984). Student Life and Exams: Stresses and Coping Strategies. Dubuque, IA: Kendall/Hunt.

Albas D. and C. Albas (1988). "The institutional staging of an examination." 'Canadian Journal of Higher Education. XVIII-1: 65-74. 
The Staging of Examinations: A Student Response

Ball, D. (1970). "An abortion clinic ethnography." In G. Stone and H. Farberman (eds.). Social Psychology Through Symbolic Interaction. Waltham, MA: Ginn-Blaisdell.

Glazer, B. and A. Strauss (1981). "A wareness Contexts and Social Interaction." In G. Stone and H. Farberman (eds.) Social Psychology Through Symbolic Interaction. (2nd ed.) New York: Wiley.

Goffman, E. (1959). Presentation of Self in Everyday Life. Garden City, NY: Doubleday.

Gross, E. and G. Stone (1981). "Embarrassment and the analysis of role requirements." In G. Stone and H. Farberman (eds.) Social Psychology Through Symbolic Interaction (2nd ed.) New York: Wiley.

Mead, George Herbert. (1964). "The Philosophical Basis of Ethics." In Selected Writings: George Herbert Mead. Edited by Andrew J. Reck. New York: Bobs-Merrill.

Perinbanayagam, R. (1974). "The definition of the situation and an analysis of the ethnomethodological and dramaturgical view." Sociological Quarterly 15: 521-542.

Stebbins, R. (1975). Teachers and Meaning: Definitions of Classroom Situations. Leiden, Netherlands: E. J. Brill. 